\title{
Geospatial modeling of the infrastructure facility optimal location
}

\author{
Olena Pomortseva, Sergiy Kobzan*, Oleksii Voronkov, and Andrey Yevdokimov \\ National University of Urban Economy in Kharkiv, 17, Marshal Bazhanov Street, Kharkiv, 61002, Ukraine.
}

\begin{abstract}
The purpose of the research is to reveal current trends in modeling the location of new catering establishments in the study area. The relevance of research in the article is determined by the development of the tourism industry. This applies to catering establishments operating in the lower price category. Such catering establishments include fast food restaurants. The article proposes to use geographic information systems for spatial analysis using software. The researchers used ArcGis software, which allows you to visualize the results of the analysis. Visualization of the results will allow to make the necessary decision on the location of catering establishments. The research was conducted on the example of the Industrialny District of Kharkiv. Analysis of geostatic models can be used to process statistical data in any locality by using a geostatistical method to convert data from a discrete view to a permanent representation. With the help of geostatistics methods, data from a discrete form are transformed into a continuous form. Researchers present mathematical formulas for determining the index of concentration of the actual population in a given area or the projected index. These indicators can be determined on the basis of data obtained during the research. Indicators are presented using elements of the ArcGis software package in discrete form and permanent form. In the research the model of optimization of placement of public catering establishments was developed. It is proposed to place twelve new catering establishments in the studied area of the city with the exact indication of their location. The scientific conclusion of the study will further improve the service to the local population and the promotion of the city of Kharkiv as a object of tourism. The principle of developing a digital map and geodatabase is effective to address issues related to tourism infrastructure, so the developed model can be used in other cities. Further research in this direction may be related to improving geostatistic analysis of data and taking into account more factors..
\end{abstract}

\section{Problem statement}

The establishment of market relations in Ukraine, the economic crisis resolution requires restructuring of the national economy, change in the traditional proportions between its branches. Priority development should be given not only to the industries the products of which will satisfy human needs, but also to the non-production sphere. Most developed countries have already gone this way. Thus, over the past 50 years the US economy has undergone dramatic changes, as a result of which the country is mainly focused on the service-producing industries. Today, the service sector provides 70 percent of gross national income and ensures 75 percent of employment, and tourism ranks first in 47 states, depending on its development. It is no coincidence that for the first time in the history of Ukraine, the government has declared tourism one of the priorities of the national economy, as the tourism business is recognized as one of the most fast-payback and highly profitable businesses. The timeliness and expediency of creating a set of measures for the development of this area of activity is based on the adoption of legislation, the main of which are the Law of Ukraine «On Tourism», Resolution of the Cabinet of Ministers of Ukraine «On measures for further development of tourism», the Law of Ukraine on the creation of special economic zones of tourist and recreational type [1]. According to the results of research carried out by the World Tourism Organization, tourism is projected to take the first place among the largest sectors of the economy in terms of revenues. Ukraine, possessing numerous historical and cultural sites, unique recreational resources, will be able to achieve a significant economic effect in the tourism business. While in the developed countries this branch of activity has become a tourism industry, Ukraine is only taking the first steps in this direction. In the world practice, the concept of «tourism industry» includes infrastructure companies engaged in satisfying the needs of tourists, including household services, local industries that produce goods and souvenirs for tourists, goods and equipment for hotels, restaurants, cafes, and also semi-finished food products, etc. A special place in the infrastructure is occupied by hotel and restaurant enterprises because they contribute to meeting such important needs of tourists as accommodation and food.

Developing the tourism industry in Ukraine, trying to enter the international market of tourist services deservingly, it is necessary to reconstruct the existing, build new modern restaurants, able to compete with the

\footnotetext{
* Corresponding author: s.kobzan@gmail.com
} 
best restaurants in the world, to gain prestige and popularity.

The solution of this problem is impossible without the development of catering establishments (CE). Unfortunately, there are many problems in this area of the national economy related to the insufficient infrastructure development, inconsistency of quantitative and qualitative characteristics with world requirements and modern needs of not only foreign but also domestic consumers, despite the fact that their percentage of financial turnover in the structure of the tourist product ranges from $20 \%$ to $50 \%$.

In addition, $\mathrm{CE}$ is an important element of the social sphere, which plays an important role in improving the efficiency of social production and, accordingly, the growth of living standards. They perform very important tasks that are related to health maintenance, leisure of citizens based on the conditions of rational use of time. Moreover, as entrepreneurial entities, they seek to increase productivity and competitiveness. The multifactorial environment of modern catering enterprises forces them to be constantly in search of new opportunities, entries into the market of food services, technology and consumers, an effective management mechanism that is sensitive and able to respond to change and act in conditions of uncertainty. In this regard, entrepreneurs should pay much attention to the organization of the catering establishment, the provision of various types of catering services, so that the establishment meets the requirements of the consumers.

One of the most important success factors, and in some cases even a dominant one, is the correct location of the catering establishment. Correction of a mistake related to a poor choice of location is possible only by re-opening the institution in another location, which entails considerable financial expenses. As a rule, the establishments operating in the lower price category, which primarily include fast food restaurants, depend on the place the most. The main principle of choosing a place for a restaurant, cafe, bar, fast food, etc. is to bring it as close as possible to the consumer. That is, the premises should be located near the places of residence of the potential consumer (near the house, near work, when walking around the city), should be accessible by transport and easy to find. Exceptions may be only superconceptual establishments, where, according to the authors' suggestion, guests will purposefully gather from all over the city. Thus, the stated above considerations allow us to justify the relevance of finding a solution to the problem of choosing the best location for the catering establishment.

Various aspects of the problem of CE development are reflected in numerous publications of both domestic and foreign researchers. Thus, in [2] the author proposed a systematization of transformational changes of classifications of restaurants by nature of economic activity, types and classes. Also on the basis of comparison of domestic and international classifications the author concludes about the need to expand the classification of restaurants in Ukraine to allow accurate statistical accounting of all existing types of restaurant establishments and to obtain reliable information for the strategic development of the industry and individual restaurant business entities. The publication [3] identifies the directions of development of the main sectors of the restaurant industry. The work [4] is devoted to the problems of restaurant chains, related to the development of competitiveness. The author of the article [5] explores the experience of overcoming the crisis by restaurant enterprises. The article [6] highlights the state of development of the restaurant industry in Ukraine, analyzes the dynamics of changes in sales of products and services, assesses trends in the number of catering establishments of different types and their profitability, identifies features and prospects for restaurant enterprises basing on the analysis. Work [7] highlights the features and impact of the restaurant business on human health, the end results of people's work and the effectiveness of Ukraine's economy.

Quite a large number of publications [8 - 11] highlight the results of research on the development of the catering industry, both in the Ukrainian realities and based on the experience worldwide. The author of works $[12,13]$ presented the research results on the efficiency of management of restaurant business strategic development, and on their basis the author concludes that possibilities of development and use of potential of restaurant enterprises of Ukraine have considerable prospects, but the current state of economy and management policy of restaurateurs determine slow development of the restaurant industry, creating a large number of obstacles in its path. In the monograph [14] the development of the theory and methodology of the economic mechanism of public catering enterprises functioning formation is investigated, their role in tourism infrastructure is analyzed, theoretical and practical bases of structuring of the tourist branch management system are investigated, suggestions on improvement of a technique which defines volumes of tourist services are given, methodical approaches of a choice of investment policy in branch model efficiency are developed. Additionally, the issues of legal and regulatory support of tourist product market existence are considered and the socio-economic essence of tourism is revealed. However, researchers absolutely do not pay attention to the formation of models of optimal CE placement.

\section{Method}

Today in Ukraine, in contrast to previous years, the approach to the foundation of public catering establishments is becoming more practical and purposeful. One of the most important steps in decisionmaking when creating a catering establishment is marketing data and consumer research, i.e. the environment in which the establishment will have to operate. In addition, it is important to find out: location features, characteristics of traffic and pedestrian flows, competitive environment, information on residential, commercial, office infrastructure. Analysis of these data allows us to conclude what type of institution should be arranged in a particular place.

Let us take a look at the general criteria for assessing 
the area of the city, which is considered as a potential place of CE activity:

Territory: area, shape, compactness.

Type of district: central - business, tourist or leisure area, sleeping, industrial, area on the outskirts of the city or outside the city.

Trends in the development of the district: whether the district is promising, and whether it can attract more wealthy visitors in the future, whether growth and change for the better is expected, or the development of the district is weak.

Characteristics of the population: population, population density, population composition. It is desirable to identify groups of the population by age and type of employment, to determine whether there are trends in the composition of the population, its wealth, the structure of households. This analysis is performed for residential areas. Office areas are studied in a similar way, with such indicators as the differentiation of enterprises by type of activity, the stability of their work, the level of wages in the area. When studying traffic flows in the area it is needed to investigate: the number, intensity, composition of traffic flows, the presence of pendulum traffic, the state of highways, road congestion, the presence of traffic jams. An important component of the analysis of the district territory is the study of pedestrian flows, which are characterized by their type (residents of the district, office workers, visitors, etc.), the intensity of each flow and time. Car and pedestrian flows are plotted on a map for the possibility to determine which of them the planned enterprise can fully use. In addition, information on the movement of public transport in the area is collected: the number of modes of transport, routes, traffic intervals, stops. Availability and level of development of existing $\mathrm{CE}$ in the area: services congestion by formats and areas of specialization, uniformity, existing niches. Future competitors are also taken into account: projects that are under construction and development, as well as the availability of vacant plots prospective for the location of catering facilities, opportunities and conditions of delivery of goods in this area, labor resources in the given territory, a situation with attraction of the personnel for the created $\mathrm{CE}$.

Unfortunately, the data that should be used in the study of the district are not always available or is fully reliable in the Ukrainian context. Such data include, for example, the level of income of the population and the volume of sales, which is on average in the CE area. Databases demonstrating the location of $\mathrm{CE}$ in the territory have not yet become widespread in Ukraine, but they may become more accessible in the future.

When exploring the area, not only a map is used, but also space and aerial photographs. Photogrammetry methods reveal many things which cannot be assessed with a topographic map, for example, when working with photography it is possible to identify disadvantaged and polluted areas, evening photographs reveal the need for light accents and suggest how pleasant and safe for visitors a visit to $\mathrm{CE}$ will be in night time.

That is, decision-making when choosing the location of a CE requires processing large amounts of information and using a set of information technologies designed to model and forecast the spatial development of infrastructure and facilities in the catering industry. Modern means of analysis of territorial location and modeling of spatial development are based on the use of geographic information technologies. Geographic information system (GIS) is an information model of real space according to the established list of features and characteristics, an active and multifunctional database that can be constantly complemented and updated. The main task of GIS is to support management decisions based on spatial analysis, mathematical and cartographic modeling, visualization, forecasting and evaluation. The use of GIS technology allows to create a detailed visualization and conduct a qualitative spatial analysis [15] of the CE placement with reference to the territory. The modeling, the results of which are presented in this paper, was done with the capabilities of the software product from Esri - ArcGIS.

Modern cities, as well as the city of Kharkiv, which was chosen as the object of study, are characterized by high population density, compact housing, the presence of four main areas of distribution: industrial, housingadministrative, utility and recreation areas. These areas involve the presence of different types of CE.

Determination of the peculiarities of the population distribution was carried out on the basis of its density indicators and concentration index. The population concentration index allows to investigate the distribution of the population by administrative units in relation to the general uniformity of its distribution across the territory. This index is calculated as the difference between the shares of the area and the population of the district:

$$
I K H=\frac{\sum\left|P_{u}-S_{u}\right|}{2}
$$

where IKH stands for population concentration index;

$P_{4}$ - the share of the population of the district;

$\mathrm{S}_{\mathrm{Y}}$ - share of the district area.

Share of the destricts area:

$$
S_{\varphi}=\frac{S_{p-\mu}}{S_{\text {обл }}} * 100 \%
$$

where $\mathrm{S}_{\mathrm{p}-\mathrm{H}}-$ stands for area of the district;

$\mathrm{S}_{\text {обл }}$ - area of the region.

Share of the population of districts:

$$
P_{u}=\frac{P_{p-\mu}}{P_{\text {об̆ }}} * 100 \%
$$

where $P_{p-H^{-}}$-stands for the population of the district;

$P_{\text {обл }}$ - the population of the region.

According to the results of calculations, the index of population concentration in Kharkiv region is $63.6 \%$, what indicates the uneven distribution of the population throughout the region, i.e. the population of the region is concentrated mainly in the central part of the region, namely in Kharkiv and suburbs.

In order to assess the sufficiency of CE in Kharkiv city, areas of the city with a high concentration of population and housing density were identified. The diagram (Fig. 1) shows that the lowest population density is in the Kholodnohirsky and Osnovyansky districts of the city, and the highest is in the Moscowsky district.

In addition, the number of catering establishments in the districts of Kharkiv was analyzed. The results of the analysis are shown on the diagram (Fig. 2). 


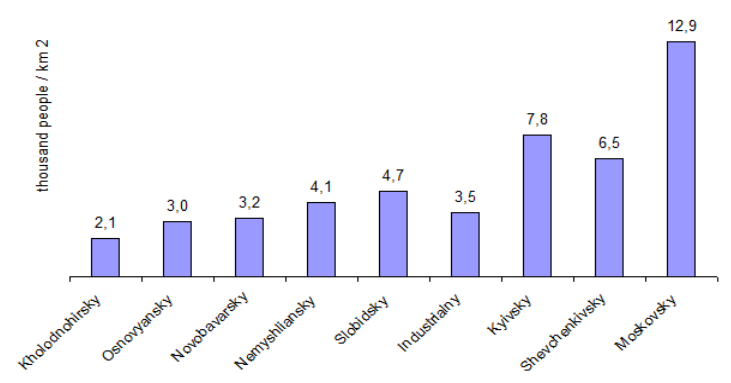

Fig. 1. Diagram of population density distribution by the districts of the city.

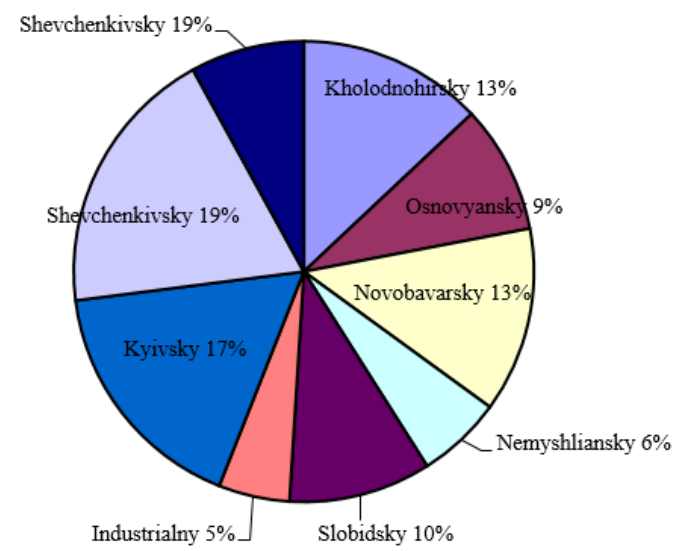

Fig. 2. Distribution of housing and communal services by districts of the city.

This diagram shows that the smallest number of CE is in the Industrialny district of Kharkiv. The obtained data were enough for further spatial analysis. As a result, a cartographic model of the territorial localization of $\mathrm{CE}$ was obtained (Fig. 3).
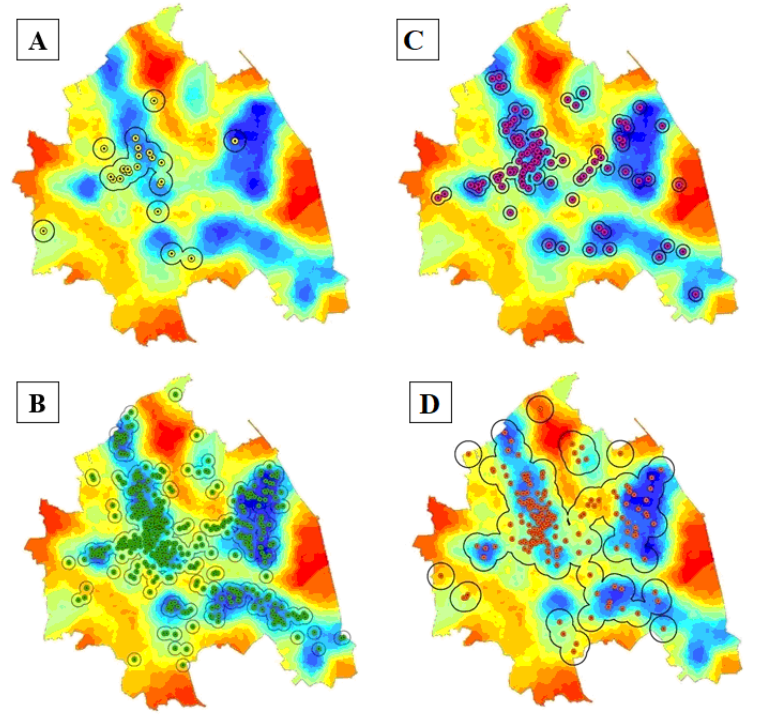

10000
5000
200

Density of population, people per $\mathrm{km}^{2}$

Fig. 3. Visualization of buffer zones for CE of Kharkiv in comparison with the indicator of urban population density. A - public dining rooms; $\mathrm{B}$-cafes; $\mathrm{C}$ - fast food establishments; D - restaurants.
Figure 3 shows that most $\mathrm{CE}$ tend to densely populated areas, which is a regularity. Our attention was drawn to the Industrialny district of the city, because it has not the smallest number of inhabitants, but the number of $\mathrm{CE}$ is much smaller comparing to other districts. While, for example, in the Shevchenkivsky district the number of CE is more than 1 per 1,000 people, in the Industrialny district this ratio is 1 per 3,000 people. It can be concluded that in the Industrialny district of Kharkiv the system of public catering establishments is not properly developed.

Here is a brief historical background about the Industrialny district of Kharkiv. The Industrialny district is a relatively young district of the city. Its foundation dates back to the first five-year plan, when the construction of Kharkiv Tractor Plant was started on the eastern outskirts of Kharkiv. Before its construction, in 1930, there was a railway station «Losieve» with three apartments and a small village Losieve with two dozen yards. Until 1941 the total population of the district was 70 thousand people. In the postwar period, intensive construction of new industrial enterprises and housing estates began. Now the district is the largest industrial district of the city. The territory of the district is 4526,8608 hectares ( $12 \%$ of the territory of Kharkiv). It borders on 2 districts: Nemyshlyansky district in the west; Kharkiv district of the Kharkiv region in the south, north and east. It is one of the greenest areas of the city. The total area of greenery is 980 hectares (including 110,2 hectares of garden squares, parks, sanitary protection zone, etc.), 264 hectares are out of balance. Its population is 153,8 thousand people $(10,8 \%$ of the population of Kharkiv). The population density amounts 3,397 thousand people per $1 \mathrm{~km}^{2}$.

Let us consider the transport infrastructure of the area. On the territory of the district there are 150 roads amounting $133 \mathrm{~km}$ long, with a total area of 1 million 118 thousand square meters, including of: citywide significance - 203,97 thousand square meters, district importance - 659.76 thousand square meters, local importance - 346,7 thousand square meters. By type of coverage: with asphalt pavement length $-87,02 \mathrm{~km}$, making up an area of 873,06 thousand square meters, with a gravel covering $32,55 \mathrm{~km}$ long, with an area of 210 thousand square meters, with a soil surface with length of $14,59 \mathrm{~km}$, an area of 100,3 thousand square meters, with a cement coating length of $4,44 \mathrm{~km}$, an area of 35.97 thousand square meters; railway stations - «Losieve-1», «Losieve-2», «Horyzont»; bus stations - «Zavodska». Characteristics of district roads - roads of citywide significance $-14,97 \mathrm{~km}$, of district significance $-72,25$ $\mathrm{km}$, of local significance $-51,38 \mathrm{~km}$.

The branch structure of the district has an industrial and commercial character and is represented by such branches as: food industry (production of soft drinks, milk and dairy products, sausages, collection, purification and distribution of drinking water); mechanical engineering (production of agricultural tracked and wheeled tractors, submersible electric motors and submersible centrifugal pumps, metal-cutting machines, bearings); construction (manufacture of concrete and reinforced concrete structures, special types of cement, expanded clay, gravel, ceramic tiles). 
There are 21 pre-school educational establishments, 19 general educational establishments, two out-of-school educational establishments and one higher educational establishment and a machine-building college in the district.

Objects of trade and consumer services are represented in the district in the amount of: 174 - shops, 246 - retail facilities, 211 - consumer services, 119 - food objects, 5 trading platforms and one market.

The housing stock of the district is 5820 houses, with a total area -5105.0 thousand $\mathrm{m}^{2}$. There are 5107 private houses in the district with total area of 640 thousand $\mathrm{m}^{2}$. There are 711 multi-storey residential buildings with the total area of 3882,7 thousand $\mathrm{m}^{2}$.

There are 6 squares with a total area of 16,44 hectares on the territory of the district.

For a more detailed analysis of the Industrialny district of Kharkiv on the ratio of population density and location of the transport network and the existing CE, a pedestrian zone with a radius of $400 \mathrm{~m}$ for each public transport stop (Fig. 4) was built with the help of GIS.

The constructed model allows to recommend placement of new $\mathrm{CE}$ in the Industrialny district of the city of Kharkiv, proceeding from the following factors:

- population density;

- transport interchange (minimization of time spent on visits);

- the presence of existing CE.

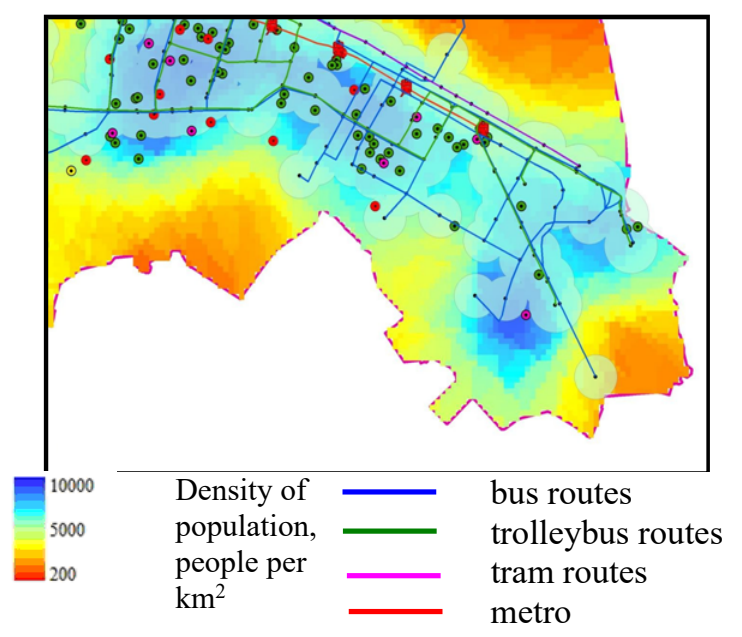

Fig.4. Outlook of buffer zones projected for public transport stops in comparison with CE sufficiency and population density indicators.

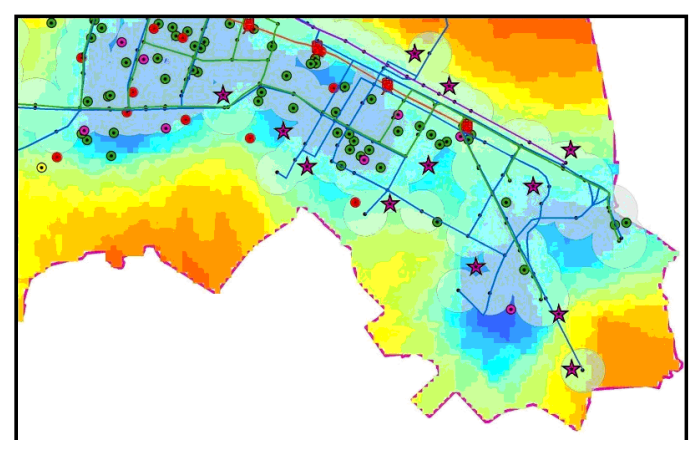

Fig. 5. View of the proposed new HVACs for the Industrialny District.

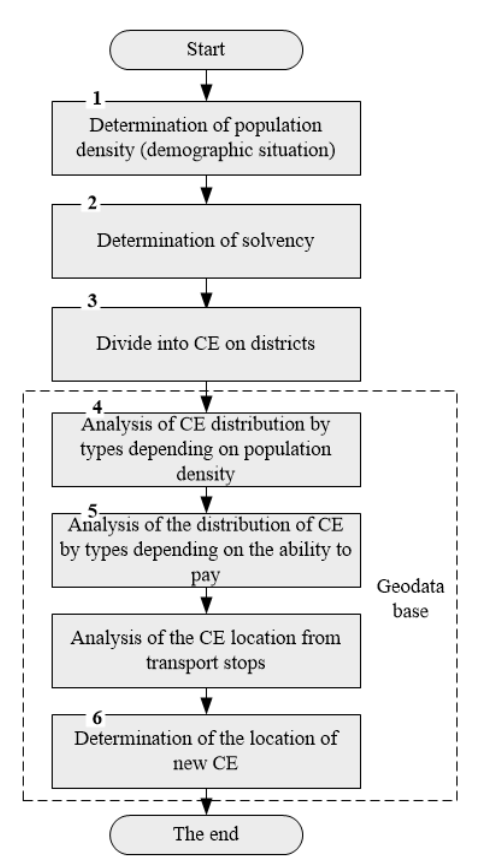

Fig. 6. Algorithm of optimization of CE placement.

As a result of the GIS analysis, 12 new catering establishments were proposed (shown by stars on the map). Particular attention when planning new CE was paid to the transport accessibility - at the intersections of large traffic flows, it was proposed to place larger restaurants, bars, cafes, snack bars and canteens and in larger numbers (Fig. 5).

One of the most important stages in creating an model of optimization (Fig. 6) for the location of CE is the development of a geodatabase, which would include a large number of influencing factors regarding the choice of location of the infrastructure object. The more influencing factors will be taken into account when creating a GIS model, the greater the opportunities will be provided in case of further spatial analysis.

\section{Results}

1. The digital geoinformation model of the Industrialny district of the Kharkiv city with introduction of a considerable quantity of attributive data is developed.

2. Calculations of the population concentration index in Kharkiv region are performed.

3. The analysis of the territory of a separate city district with the help of geographic information systems on the identification of the optimal number and rational placement of catering facilities is performed.

4. An model of optimization of CE placement based on the results of analysis of a number of factors has been developed.

\section{Conclusions}

The use of geoinformational technologies to model the location of new $\mathrm{CE}$ will allow to take into account many factors, namely, population density, purchasing power, distance from traffic stops, and to solve this problem with 
minimal time costs and with the least probability of error. It was with the help of spatial analysis performed in the ArcGis geoinformational system that the creation of twelve new catering establishments in the Industrialny district of Kharkiv was proposed, as in the least provided with such establishments district.

In the research, with the help of the ArcGis software package, an optimization model for the location of CE was developed and a map of the existing $\mathrm{CE}$ of the Industrialny district of Kharkiv was compiled. This map provided an opportunity to further establish the number and location of new CE. Further it will also allow not only to improve the service to the local population, but will also encourage the promotion of the city as a tourist attraction.

The very principle of building a digital map and database structure will be effective to address any issues related to tourism infrastructure, so the developed models can be distributed among any administrative units. In general, data mining of geostatic models can be used to process statistics in any locality by using a geostatistic method to convert data from discrete to permanent representation. Further research in this direction may be related to improving geostatistic analysis of data and taking into account more factors.

As an example, mathematical formulas were presented to determine the index of concentration of the actual population in a given area or the projected index. These indicators can be determined on the basis of data obtained during the study and presented using elements of the software package ArcGis in discrete and constant forms.

\section{References}

1. Law of Ukraine On Amendments to the Law of Ukraine «On Tourism» and Certain Other Legislative Acts Concerning the Basic Principles of Tourism Development, http://search.ligazakon.ua/1_doc2.nsf/link1/JI03317 A.html. Accessed 28.09.2020

2. O.M. Kravchenko, I.I. Sokoly Classification transformation in the food sector. Economics: the realities of time. 2 (12), 150 - 158 (2014)

3. A.O. Avetisova Directions of development of the main sectors of the restaurant industry Trade and market of Ukraine 19. - Vol. 3, 147 - 151 (2005)

4. G. Pyatnytska Conceptual principles of restaurant business development in Ukraineka. Bulletin of KNTEU 3, 15 - 23 (2008)

5. A.O. Avetisova Restaurants come out of the crisis: experience and problems, Trade and Market of Ukraine 31 (1), 3 - 8 (2011)

6. L.I. Miner, V.A. Verb Current state, prospects and trends in the restaurant industry in Ukraine, Economics and business management 16, 71 - 76 (2018)

7. V.A. Antonova Restaurant business in the economic development of Ukraine, Economic strategy and prospects for the development of trade and services,
Release. 1 (11), 595 - 601 pp. (2010)

8. P. Zaremba, V. Kiyko Development of the restaurant industry of Donetsk region, Goods and markets $\mathbf{1}$ (15), 35 - 42 (2013)

9. V.V. Krivoshey Peculiarities of development of enterprises of restaurant economy of Kharkiv region, Annual Sciences. Journal of the Donetsk Institute of Tourism Business. Ser. Economics, organization and management of enterprises of the tourism industry and the tourism industry in general 16, $263-267$ (2012)

10. V.V. Krivoshey Peculiarities of restaurant business development, Economics: trade, analysis, practice 1, $51-62$ (2012)

11. V.M. Selyutin, D.Ye. Shevchenko Problems and prospects of culinary tourism development in Kharkiv region, Economic strategy and prospects for the development of trade and services 1 (15), part 2, $349-358$ (2012)

12. I.V. Skavronska Priority directions of development of restaurant business of Ukraine in the context of world experience, Bulletin of the Chernivtsi Trade and Economic Institute, № 2, 232 - 245 (2009)

13. O.B. Borusova Tendencies of development of hotel and restaurant business in Ukraine, Economic strategy and prospects for the development of trade and services 1 (15), part 2, 331 - 338 (2012)

14. V.A. Antonova Restaurant business: the mechanism and effectiveness of strategic development management: a monograph, Donets. nat. University of Economics and Trade. Tugan-Baranovsky. Donetsk: Don NUET, 277 p. (2000)

15. O. Pomortseva, O. Kobzan, S. Yevdokimov, A. Kukhar Use of geoinformation systems in environmental monitoring, E3S Web Conf. 166 (2020) 